\title{
THE ROLE AND SIGNIFICANCE OF USING THE VISUAL-COGNITIVE APPROACH IN HIGHER EDUCATION
}

\author{
Alimov Azam Anvarovich \\ Head of the Department "Oil Refining \\ Technology", \\ Bukhara Engineering -Technological Institute \\ (Uzbekistan) \\ Tosheva Gulnora Djurayevna \\ Applicant, Bukhara Engineering - \\ Technological Institute (Uzbekistan)
}

\author{
Xo'jjiyev Ma'murjon Yangiboyevich \\ Applicant, Bukhara Engineering- \\ Technological Institute (Uzbekistan)
}

\author{
Muminjonova Muhayyo Gulomovna \\ Applicant, Jizzakh regional center for \\ retraining and advanced training of public \\ education workers
}

Article DOI: https://doi.org/10.36713/epra4823

\section{ANNOTATION}

This article discusses visual programs and their capabilities aimed at organizing higher education today. Based on innovative foreign experience, it is possible to fully understand the goals and objectives of science by further developing its methodological aspects. The development of visualized methodological support makes it possible to make fundamental aspects of science widely unknown.

KEYWORDS: visual, 3D model, video, Delphi, Flash program, cognitive-visual, content.

\begin{abstract}
Аннотация
В данной статье рассмотрены визуальные программы и их возможности, направленные на организацию высшего образования на сегодняшний день. Опираясь на инновационный зарубежный опыт, можно в полной мере понять цели и задачи науки путем дальнейшего развития ее методических аспектов. Развитие визуализированного методического обеспечения позволяет сделать фундаментальные аспекты науки широко неизвестными.

Ключевые слова: визуально-когнитивный подход, 3D-модель, видео, Delphi, Флэш-программа, когнитивно-визуальный, контент.

\section{INTRODUCTION}

Currently, 3D technologies are widely used in almost all technical industries around the world.

Excellent organization of classes in continuing education is the primary task of the teacher. Opportunities for efficient use of available resources lead to a rapid increase in the volume of information and speed up its exchange. In this rapidly developing society, it is difficult to be a skilled, Mature competitive value without mastering the skills of using modern ICT, carefully mastering professional knowledge and skills. In particular, 3D graphics are effectively used in education. 3D

graphics is a section of computer graphics that uses technical tools for managing three-dimensional images and sites in three-dimensional space. You can use it to represent objects as "flat " images using a $3 \mathrm{D}$ graphic object, such as a projection or 3D animation. Due to the fact that $3 \mathrm{D}$ graphics and technologies are conquering the whole world, it is also used in science, industrial technology and architecture in various spheres of society. It is also widely used in movies and video games. It is very convenient to use in education and gives effective results in mastering topics quickly and visually. In 3D graphics uses a virtual camera when creating
\end{abstract}


animation in the rendering process. This type of camera has many conveniences in explaining how to view 3D models.

Image and video visualization is actually a virtual photo and video image, so when working with a scene, you use objects like "Camera" (Camera). You can set up any number of cameras on the stage that record different angles.

\section{VISUAL PROGRAMMING}

As part of the fifth generation of development of EXM, EXM, much more advanced "man-machine", databases, expert systems, etc. determining the creation of interfaces, the next intellectualization begins to be implemented.

The development of operating systems began in the early 1980s with the appearance of graphical interfaces (Windows, Linux idr.) led to the appearance, they became widespread by the end of the decade.

By its nature, the graphical interface is a component of the system. The purpose of creating it is not to introduce new functionality, but to improve the connection between graphical controls and functions of internal parts of the application. An event handling mechanism was created (which any program knows when it is running or interacting with someone). Program code elements interact and start working when certain events occur. The program code structure is probabilistic. All routes and code routes are not strictly defined. Developing a graphical interface using traditional programming languages takes up to $50 \%$ of the time to create an application.

One of the most popular models that appeared in the early 90s of the last century is Rapid Applications Development (RAD), or the rapid application creation model. It is based on major improvements made in four areas, which include:

i. tools-source code generators, tool (s) layout tools, and fourth-generation programming languages;

ii. methodology-optimization of the application development cycle;

iii. recruitment of highly qualified and interested personnel;

iv. choosing an innovative management strategy.

The introduction of fast visual tools for app developers has increased the speed of creating a graphical application interface. Rapid development of applications is the creation of a layout (prototype) of applications. The application layout consists of components (components) that form a visual programming environment, an object-oriented lineage. Each component of this genome has a set of properties that are determined by its behavior and its own response to events occurring in the operating system. Creating a graphical application interface is similar to the game "constructor".
However, creating an app layout does not mean that the app code will be sufficiently efficient and high-quality. As a rule, rapid application development languages are interpreted (analyzed). This fact can be attributed to two reasons:

i. In cases when interpretation is used, simplifies the interpreter. In particular, the compiler loses the component of generating machine codes, which has a serious complexity. As a result, the rapid development tool can be applied faster. A work-worthy version of the app will also be received faster.

ii. The use of machine-dependent intermediate coding technique not only eliminates the problem of transferring (or at least internationalizes) information systems created on its basis, but also eliminates the problem of transferring (or at least interprets) the development tool itself for the new platform.

But in any case, the interpreter remains an interpreter that cannot effectively execute a program like a computer. But in the mid-90's, Borland developed the Delphi visual programming environment, which provides code creation by compilation, which provides code creation by compilation. This is another step in the development of rapid development tools.

Here are some important aspects of visual programming:

1. based on the visual programming environment, which has the following advantages, lies in event programming:

a. the user of the program determines the order of its execution;

b. when an event-driven program is idle, it uses almost no computer resources, which allows the computer to perform other tasks;

c. using events simplifies programming, because instead of constantly checking each input device, it waits for the operating system to report an incident;

d. events also allow applications that define their own behavior to work with objects.

2. The operating system passes events to the object, while the object's event handlers determine how it will be processed. The program does not need to know the structure of the object, it only needs to know how to handle the object.

3. Visual programming changes the design scheme of an application: programming begins with viewing the appearance of the application (the application interface), which allows the user and programmer to develop 
a view of the work that makes the application the only view. The ability to quickly layout applications related to enterprise-level technologies opens the way to developing projects of any scale, both wavy and predictable.

4. Building the visual programming environment and applications in which it will be developed is based on the principles of object-oriented programming.

5. in Addition, the ideas of modular programming have reached logical accuracy in the languages of the visual programming environment.

CASE-Technology (Computer Aided Software Engineering-software development automation)

The developer begins his work by planning large programs, drawing some diagrams, writing some preliminary specifications, creating some layout that allows you to determine how all the components interact, how to solve the problem. In the $60 \mathrm{~s}$, this process was formed using blockchain schemes. With their help, they tried to explain all the stages of program development. Even there were schemes, special workstations for automating the development process. The idea of a complete description and management of development is called software engineering. Software engineering is the science that allows you to build complex software with predictable style and measurement and guaranteed quality. It was an attempt to automate personal work. In the $80 \mathrm{~s}$, software development automation systems, or system analysis systems, began to appear, designed for system analysts and designers who were not intended to be used throughout the software lifecycle. These include tools for applying graphical models, designing specifications, and data dictionaries. Experts developed the program by drawing its logical structure, showing on the screen what to do and in what order. After the structure was drawn, you could start creating the program code.

The second stage of development of case tools is characterized by more developed capabilities of tools and a complete approach to the life cycle. First of all, in different third-and fourth-generation languages, it was necessary to specify support for automatic code generation, which could include manual correction and insertion, allowing you to see the product skeleton. Information about graphic requirements, design specifications, project management, analysis, and system information is provided by functional support. It comes with tools for testing, verifying (verifying), generating (generating) programs, and analyzing the production of project documentation.

The attitude is not the same. On the one hand, the fact is that technologies have high reserve capabilities for increasing labor productivity, improving the quality of software products, and maintaining a uniform and consistent work style. At the same time, existing case tools, using methods of structural and object-oriented analysis and program design, can be attributed to various tools for describing external requirements, relationships between program creators, and work dynamics (for example, diagrams, texts, etc.).

Another point of view is that CASETechnology evaluates that drawing and diagrams are nothing more than a design package.

\section{LET'S LIST THE MAIN CHARACTERISTICS OF THIS TECHNOLOGY}

i. the methodology of system analysis became the basis of the case technology;

ii. When developing using CASE systems, the main amount of work was distributed at the initial stages of the software lifecycle, and the creative factor was considered important. Using CASE minimizes the complexity of the coding stage and significantly reduces product testing time.

iii. Integration of individual founders of CASE tools provides management of the information system development process.

iv. Using a specially created project meta-data repository (repository) ensures that project versions and individual organizers are saved, and that information received from different vendors is synchronized when working in a group, so that meta-data is not complete and contradictory.

But there are also disadvantages of case tools. One of them is that any automated design system has its own specification, and the system will never reflect the requirements of this user $100 \%$ or, if the CASE system is powerful and multifunctional enough, the system will take a long time to master it. History repeats itself. More and more apps are required.

Programmers will need computer-based design tools. Study of the structure of pedagogical activity of V. p. Bespalko, T. E. Bobudko, N. V. Kuzmina, V. A. Slastenin, Yu. G. It is devoted to the scientific research of Tatur and other similar scientists.

N. V. Kuzmina [1] identifies the main functional components of pedagogical activity, which include: Gnostic (depending on obtaining information about all aspects of pedagogical activity); project (the content of which consists of forming and reformulating pedagogical goals and objectives, updating old plans and programs of training and education and drawing up new ones); constructive (in fact, the process of modeling, drawing up a plan for upcoming training, equated to 
its preparation); organizational (reflects the actual activity performed for the practical application of the established curriculum or program); communicative (includes procedures that ensure the necessary relationships and connections between various participants in the educational process).

G. A. Kruchinina [2] showed the necessary pedagogical skills in using new information technologies (new information technologies) in the structure of pedagogical activity:

\section{Gnostic skills:}

i. $\quad$ selection of the main topic for the content of the textbook in the characteristics of the use of new information technologies;

ii. formation of goals for the use of new information technologies in the classroom, elective classes;

iii. identification of the main topic in the content of computer programs, assessment of the need to use the appropriate specific training program;

iv. assessment of the interest of individual groups of students in working with training programs, depending on the type of tasks, their degree of complexity in one form;

v. V. analysis of possible ways to use new information technologies, revision of the work based on objective requirements;

vi. comparison of individual assessment with the assessment of students provided for the use of various types of training programs;

vii. Ver. assessment of individual readiness for pedagogical activity in the conditions of new information technologies.

\section{Constructive skills:}

i. development of summaries of various types of educational and cognitive activities of students with the inclusion in the system of activities of the curriculum "Teacherstudent-computer-student";

ii. taking into account the individual characteristics of the student when reading using a computer, anticipating their difficulties;

iii. analysis of the content of the entire course, writing scenarios of training programs, a separate topic of the lesson;

iv. development of problem-cognitive and creative tasks, search work of the student on working with a computer program, educational games, etc.;

\section{Organizational skills:}

i. management of educational-cognitive activity of pupils in conditions of the use of new information technologies in the classroom, extracurricular activity, independent training circle on the subject, the contest of knowledge; ii. the implementation of the organization of individual, group and collective activities on the computer use at different stages of the lesson;

iii. working with different groups of students and objective evaluation of their activities;

iv. system monitoring of students ' activities both in a computer and in a complex (computer-pedagogical) way.

\section{Communication skills.}

i. in the context of using new information technologies, from a pedagogical point of view, establishing purposeful relationships with students, stimulating interest in classes;

ii. if it is difficult for the reader to complete the task, analyze how clear the tasks, "help" that are given in various types of educational programs are for him;

iii. assessment of students ' interest in working with programs in order to establish a better teacher-computer-student relationship;

iv. the creation of creative search of the atmosphere;

v. V. creating a positive attitude to the use of the computer in training sessions;

vi. to predict the reaction of readers to establish an emotional connection.

\section{Project skills.}

i. determine the place of use of computer programs in the context of a particular lesson, the type of program that is most suitable for the tasks;

ii. The ability to plan the study of the entire topic (lesson system) using new information technologies;

iii. teaching the results of using new information technologies as a means of teaching and developing students, planning. Having considered the structure of pedagogical activity and methodological features of teaching oil and gas, T. A. Lavina [3] defined the content of the main organizers of the activity as follows:

The constructive component (organizer) takes into account the skills of planning the educational process using new information technology tools:

i. determine the pedagogical feasibility of using modern new information technologies (modern new information technologies), taking into account the purpose of training, the content of the material being studied, the age characteristics of students, their knowledge and interests in the learning process;

ii. taking into account the capabilities of new information technologies;

iii. analyze the capabilities of modern information technologies in order to 
determine their feasibility in the educational process (description, consolidation, repetition, control of new knowledge in preparation for the lesson).;

iv. selection of effective methods of using Informatization tools in the educational process;

v. V. implementation of lesson planning using information technologies;

vi. use of information and methodological support for the educational process.

\section{IT ASSUMES THE PRESENCE OF SKILLS RELATED TO THE GNOSTIC COMPONENT}

i. Study and analysis of the possibilities of new information technology tools;

ii. evaluation of software for educational purposes (expert evaluation of software for educational purposes);

iii. iii.study and analysis of the activities of individuals and students in the application of new means of Informatization of education.

iv. The designer assumes that they have skills related to the production of educational software.

\section{THE ORGANIZATIONAL COMPONENT INVOLVES THE AVAILABILITY OF SKILLS FOR THE SYSTEM OF EDUCATIONAL WORK WITH USE OF MODERN INFORMATION TECHNOLOGIES}

i. preparing for the introduction of modern information technologies;

ii. using the ZAT at different stages of the class;

iii. to familiarize readers with instructions for work with modern information technologies;

iv. the exercise of independent activity to work with modern information technologies;

v. the organization of independent work of students using modern information technologies;

vi. organization of students ' work in groups and individually with modern new information technologies;

vii. creating motivation for students to work with ZAT;

viii. perform a selection of tasks that include performing training activities using modern information technologies.

\section{REQUIRES SKILLS IN THE COMMUNICATION COMPONENT}

a. working in a learning environment organized by the local network of the training and computing complex;

b. the use of modern information technologies in the context of telecommunications.

$\mathrm{T}$. V distinguish the following types of Extracurricular activities [4].

"Information-oriented activities. Search and processing of information necessary for the implementation of the set or formulated goals of pedagogical activity from the outside. Understanding the pedagogical problem. Formation (or awareness of what is given from the outside) of the goal of pedagogical activity aimed at solving the problem. Updating, searching, processing (descriptor stage) of information necessary for the implementation of a formulated or set goal. Getting independent education.

Modeling activities. Building information models of the educational process, algorithms of pedagogical activity. Interpretation and decomposition of goals. Transformation of descriptive information into written form: development of curricula, programs, manuals, etc. (prescriptive stage).

Mobilization activities. Formation of cognitive activity of students. Establish purposeful relationships with all DJs involved in the teaching process. Creating the necessary psychological climate, forming students ' satisfaction with educational and cognitive activities. Development and stimulation (implementation stage) of motivation, interest in educational and cognitive activities among students.

Broadcast activities. Broadcast social experience.Assimilation (implementation stage) of social experience transmitted by students.

Control and Evaluation activities. Evaluating the effectiveness of the social experience transfer process. To study the existing capabilities of students, their levels of mental development. Formation of an information base for analytical activities of students and The center for the information base of educational and cognitive activities (implementation stage).

Analytical activity. Theoretical analysis ("retrospective stage") of practical activities in order to adjust it if necessary during the next pedagogical cycle.

In the framework of the constructed model $\mathrm{T}$. V. Dobudko allocated the algorithm structure of the professional activity of teachers of oil and gas:

i. In the framework of information-oriented activities teachers of oil and gas provides for the development of new algorithms for information-oriented activities, such as the possibility of new means of information 
technology implementation as a tool of cognitive activity, the algorithms independent reading teacher of oil and gas in the framework of remote forms of working and learning in computer networks.

ii. II. the Specifics of the simulated activity of the oil and gas teacher is based on the need to master algorithms for selecting the broadcast educational content using modern information technologies, algorithms for optimal distribution of broadcast functions and control and evaluation activities in the teacher-computer system, algorithms for modeling activities related to the organization of team-cognitive activities.

iii. Changes in the composition of the analytical activity of the oil and gas teacher are related to the algorithms of interpretation (analysis) and primary statistical processing of the results of control and evaluation activities using new information technology tools, algorithms for the use of expert systems implemented in analytical activities based on the pedagogical knowledge base system.

iv. The specificity of mobilization, translation, monitoring and evaluation activities of teachers of oil and gas is characterized by the following set of new algorithms: algorithms mobilization activities implemented in individual work with students in the application of new information technologies, algorithms mobilization activities during the participatory learning activities, modern information technology (training programs, algorithms, providing translational activities using simulation and modeling software environments of expert systems), algorithms that implement feedback in the "teacherstudent " system based on modern information technologies, algorithms for pedagogical assessment within the framework of modern information technologies.

In accordance with the constructed model of activity of the oil and gas teacher, a cycle of disciplines aimed at training future teachers in the methodology of teaching oil and gas and new information technologies of training, as well as providing General scientific training in the oil and gas industry (Fig. 1): 


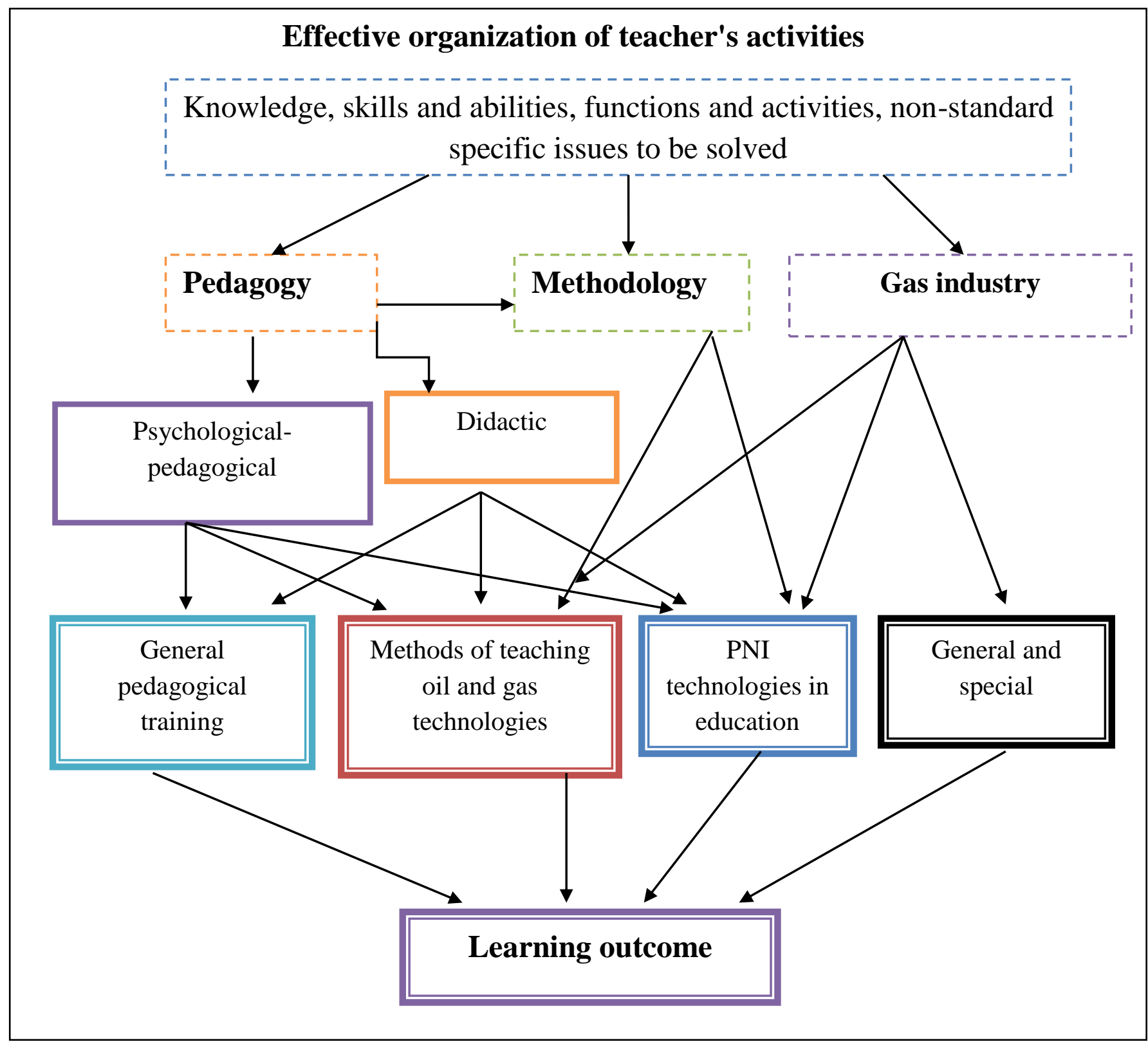

Figure 1. Improving the process of organizing the activities of a teacher of the oil and gas industry

In accordance with this model, a graduate of a pedagogical University is required in the main areas of education: pedagogical, methodological and scientific level of oil and gas, according to which, when preparing a teacher of oil and gas, a block of pedagogical Sciences, a block of methodological disciplines and a block of subject disciplines are allocated.

Depending on the tradition of continuous growth of knowledge, the school needs a teacher with fundamental knowledge in the field of information.

\section{CONCLUSION}

The oil and gas teacher must be prepared to perform all the tasks that may be assigned to him at school. To do this, the student must not only know the scope of the oil and gas school course, but also have a certain amount of knowledge in various areas of oil and gas development (Programming, databases, algorithm theory, computer networks).

At the same time, mastering programming technologies will allow the future teacher of oil and gas science to form a complete picture of the history of programming development, show the principles laid down in software at the programming level, develop skills in developing high-quality software 
products, and prepare for specialized programming courses.

Currently, programming skills in the visual programming environment are becoming promising in the professional activity of an oil and gas teacher.

\section{REFERENCES}

1. Кабанова-Меллер Е.Н. Учебная деятельность и развивающее обучение. - М.: Знание, 1981. -96 с. (Новое в жизни, науке, технике. Сер, «Педагогика и психология». > fe6.)

2. Инькова Н.А. Методика организации учебноинформационной гипермедиа-среды изучения образовательной области «Информатика». Дис.... канд. пед. Наук. Тамбов, 2000.

3. Корнетов Г,Б, Гуманистическое образование: традиции и перспективы, -M,, 1993.-71 с,

4. Григорьев С.Г., Гриншкун В.В. Технология информационного интегрирования в разработке учебников и учебных пособий для Интернет. «РЕЛАРН-2001» Материальг конференции. Петрозаводск, 2001.-С. 166-167.

5. Alimov, A. A., Savrieva, I. B., \& Amonov, Е. И. (2019). METHODS OF IMPROVING THE QUALITY OF TRAINING OF QUALIFIED ENGINEERING STAFF ON THE BASIS OF PERSONALITYORIENTED INNOVATIVE TECHNOLOGIES. Информачия и образование: границ̧ь коммуникаиий, (11), 76-78.

6. Khamidov Jalil Abdurasulovich, Khujjiev Mamurjon Yangiboevich, Alimov Azam Anvarovich, Gafforov Alisher Xolmurodovich, Khamidov Odil Abdurasulovich. "OPPORTUNITIES AND RESULTS TO INCREASE THE EFFECTIVENESS OF MULTIMEDIA TEACHING IN HIGHER EDUCATION." Journal of Critical Reviews 7 (2020), 89-93. doi:10.31838/jcr.07.14.13

7. Хўжжиев, M. Я. (2020). ВОЗМОЖНОСТИ ПОВЫШЕНИЯ ЭФФЕКТИВНОСТИ МУЛЬТИМЕДИА В ПРОЦЕССЕ УРОКА.Universum: психология и образование, (1), 10-13.

8. Muradilloyevich, Ibragimov Ulugbek, Olimov Kaxramon Tanzilovch, Alimov Azam Anvarovich, and Savriyeva Iqbol Baxodirovna. "IMPROVEMENT OF TEACHING METHODOLOGY BY USING MODELING PROGRAMS OF ENGINEERING EDUCATION IN HIGHER EDUCATION OF UZBEKISTAN." JournalofCriticalReviews 7, no. 14 (2020): 81-88.

9. Alimov, Azam A., Kakhramon T. Olimov, and AlisherKhGaffarov. "Preparing Future Teachers of Vocational Education for Innovative Activity in Uzbekistan." Eastern European ScientificJournal 2 (2018).

10. Alimov, Azam A. "Improving the Training the Future Teachers of Special Disciplines in Uzbekistan." Eastern European Scientific Journal 1 (2016): 113117.

11. Алимов, Аъзам Анварович. "Соверменствование прочесса подготовки будущих преподавателей специальных дисичилин." Europeanresearch 8 (9) (2015).
12. Алимов, Анвар Танзилович, Каюм Бешимович Хаджиев, ап Аъзам Анварович Алимов. "Применение метода единичных случаев в лабораторном обучении."Молодой ученый 4 (2013): 506-507.

13. Жураев А.Р., Тешаева И.М. Методические основания оптимизации содержания предмета «Технология». "Проблемы науки” научнометодический журнал № 6 (30) / 2018 г. Россия, Москва с $88-89$.

14. Zhuraev A.R.Using Electronic Teaching Materials for Training Future Teachers // "Eastern European Scientific Journal”. Auris Kommunikations - und Verlagsgesellschaft mbH. Journal ausbage $1-2019$. Germany. $P g, 432-435$.

15. Rashidovich, Bazarov Gayrat, Abdurakhimov Saidakbar Abdurakhmanovich, and Alimov Azam Anvarovich. "STUDYING THE POSSIBILITY OF USING MECHANICAL-CHEMICAL DISPERSION FOR INCREASING THE SALT-STABILITY OF CLAY DRILLING SOLUTIONS." Journalof Critical Reviews 7, no. 14 (2020): 72-74.

16. Давронов, Ф. Ф. У., \& Хужжиев, М. Я. (2018). Изучение прочесса очистки газов физической абсорбцией. Вопросы науки и образования, (3 (15)).

17. Хужжиев, М. Я. (2018). Изучение методов конверсии метана в синтез-газ. Научный аспект, 7(4), 852-854.

18. Усанбоев, Ш. Х. У., \& Хужжиев, М. Я. (2017). Основные свойства катализаторов гидроочистки. Вопросы науки и образования, (5 (6)).

19. Кобилов, А. Б. У., \& Хужжиев, М. Я. (2017). Механизм поглощуения H2S, CO2 и других сернистых компонентов водными растворами аминов. Вопросы науки и образования, (11 (12)).

20. Бурхонов, И. У., \& Хужжиев, М. Я. (2017). Сравнительный анализ эффективности работь аппаратов воздушного и водяного охлаждения нефтеперерабатываюших заводов. Вопросы науки и образования, (2 (3)).

21. Ризаев, Д. Б., \& Хужжиев, М. Я. (2017). Очистка газовых выбросов. Вопросы науки и образования, (5 (6)).

22. Хужжиев, М. Я. (2016). Очистка и осушка газов растворами гликолей. Наука и образование сегодня, (3), 33-34.

23. Хужжиев, М. Я. (2016). Изучение прочесса риформинга и подготовки нефтепродукта. Наука и образование сегодня, (3 (4)).

24. Хужжиев, М. Я., \& Хайдаров, Г. А. У. (2016). Изучение характеристики физических поглотителей для очистки газов.Наука и образование сегодня, (3 (4)).

25. Alijono'g'li, S. J. CHOICE OF REFINING METHOD AND COMPLEX PROCESSING OF USED OILS TO OBTAIN VALUABLE PRODUCTS. EPRA International Journal of Multidisciplinary Research (IJMR), 75.

26. Жасур, С., Бакиева, Ш. К., \&Нуруллаева, 3. В. (2016). Технологчческие схемы прочессов депарафинизации. Наука и образование сегодня, (3 (4)). 